Pearson, L, Sands-O-Connor, K and Subramanian, A, 'Prize Culture and Diversity in British Children's Literature', International Research in Children's Literature 12:1 (2019), 90-106.

\title{
Prize Culture and Diversity in British Children's Literature
}

Lucy Pearson, Karen Sands-O’Connor, Aishwarya Subramanian

Literary prizes often determine eligibility in terms of nationality; this article posits that they also play a significant role in constructing national literatures. An analysis of the Carnegie Medal, the UK's oldest children's book award, and some of its competitors, including the Guardian Prize and Other Award demonstrates the tension between the desire to claim cultural value for children's literature and to construct a body of literature that represents the real and imagined community of the nation. In the UK, this tension appears most notably with regard to depictions of Black, Asian and minority ethnic Britons.

Key words: diversity, United Kingdom, Carnegie Medal, Guardian Award, Other Award, national literatures

In 1937, announcing the establishment of the Carnegie Medal for 'the best book for children published in the British Empire', the Library Association Record noted that 'Originality in such an action is, of course, not claimed because we already have in America the capital example of the Newbery Medal' ('Carnegie Medal'). The implicit note of rivalry reflects Pascale Casanova's contention that 'literary capital is inherently national' and that national literatures are 'constructed through national rivalries' $(34,36)$. For Casanova, literary prizes function primarily as a means of 'making the verdicts of the sanctioning organs of the republic of letters known beyond its borders' (146), but as James English shows in The Economy of Prestige, they also play a significant role in negotiating different types of capital both within and beyond the nation. Furthermore, prizes are in effect a form of curation: they do not simply disseminate the 'verdicts' of the wider literary culture but are involved in a process of selection and definition that ensures at least some degree of preservation for the honoured texts. Prize winners necessarily cannot represent the entirety of a national literature, but the act of selection works to construct a set of judgements about what might be termed a 'national literary heritage'. The national rivalry suggested in the first Carnegie announcement 
Pearson, L, Sands-O-Connor, K and Subramanian, A, 'Prize Culture and Diversity in British Children's Literature', International Research in Children's Literature 12:1 (2019), 90-106.

thus hints both at the function of prizes as a means of claiming cultural prestige and at their role in constructing the 'imagined community' (Anderson) of the nation. These functions are not necessarily compatible. The history of children's book awards in the UK demonstrates an uneasy relationship between the desire to claim aesthetic and cultural value for British children's literature and the question of how it represents the real and imagined community of the United Kingdom. This tension has largely been resolved by prioritising abstract ideals of literary quality over considerations of readership and diversity.

The Newbery Award has served as a baseline for children's literary awards in the USA, becoming the 'Nobel' of the field against which other prizes define themselves (Kidd 168). The Carnegie Medal has functioned in a similar way in the UK: despite varying levels of publicity over its eighty-year history, Medal winners enjoy considerable prestige and longevity. In 2019, two-thirds of Carnegie winners remain in print, including many from the first two decades of the award; it is still considered, in the words of winner K. M. Peyton, 'the one to win' (in Sperling). It has also exerted its own 'logic of proliferation' (English 50): while a host of prizes have been established since the 1930s, new prizes are still apt to distinguish themselves against the Carnegie Medal, as will be seen below. It thus exerts a gravitational force over the construction of 'national literature' curated by children's book awards in the UK.

\section{Nationality and Belonging: The Carnegie Medal}

Mark Macleod notes that the current Carnegie criteria - unlike those of comparable awards in the USA or Australia - do not specify the author's nationality, commenting 'Nationality is more important to the provincial and postcolonial than to metropolitan society' (35). This reading, however, overlooks the degree to which the Medal has been implicated in questions of national identity throughout its history. In fact, the histories of the Carnegie Medal and its 
Pearson, L, Sands-O-Connor, K and Subramanian, A, 'Prize Culture and Diversity in British Children's Literature', International Research in Children's Literature 12:1 (2019), 90-106.

competitors reveal a continual and often painful negotiation of the stakes involved in creating a national literature.

Discomfort about parameters of nation and national identity was evident from the beginning. The subcommittee responsible for founding the Carnegie Medal proposed that it go to 'the best children's book published during the year by a British author' (Library Association Minutes 1935, in Barker, Carnegie Medal 1), but when the Medal was announced, the question of the author's nationality was apparently forgotten in favour of a specification that the book should simply have been published 'in the British Empire' ('Carnegie Medal'). A clarification that the author 'must be British' was published the following year ('Library Association Carnegie Medal' 1937, but the first year's shortlisted titles all understand nationality and belonging as functions of place rather than birth. The two highly commended books for 1936 both feature characters from refugee populations who become British by adoption. In Noel Streatfeild's Ballet Shoes, Russian-born Petrova is uncomfortable with the assumption she will be especially pleased to perform in a charity performance for a hospital that has provided aid to another Russian refugee: 'though of course she was very glad to help the hospital, it was not because she was Russian; for she was British by adoption, and had taken a British name, and felt very British inside' (104). Petrova's 'British name' is 'Fossil', a surname that symbolically connects her to history and landscape. Similarly, in Howard Spring's Sampson's Circus, orphaned Belgian refugee Jacques asserts his Britishness by adopting the name Jack. Raised by an English family, when he discovers he is heir to a Belgian fortune he emphasises his connection with British space, complaining 'I was happy enough where I was' (323). These two books are simultaneously inclusive and imperialistic: it is both possible and desirable to become British (at least if you are white - Spring's treatment of race is profoundly othering) but at the cost of complete assimilation (Petrova cannot conceive of herself as both Russian and British). 
Pearson, L, Sands-O-Connor, K and Subramanian, A, 'Prize Culture and Diversity in British Children's Literature', International Research in Children's Literature 12:1 (2019), 90-106.

A similar concern with questions of belonging is evident in the winner of the inaugural Medal, Arthur Ransome's Pigeon Post (1936). The sixth novel in Ransome's Swallows and Amazons series, Pigeon Post returns to the Lake District setting for which his books are best known. Ransome's child characters style themselves as 'explorers', casting adults as 'natives' and colonising the adult landscape. In this novel, however, tensions around the children's outsider status - all but two are visitors to the area - are foregrounded. Prolonged drought has provoked fears of fell fires, making local farmers - literal as well as figurative natives to the area - reluctant to allow the children to camp. Only after a series of incidents that serve to demonstrate the children's connection to the land and its traditions are they fully accepted. Identity and belonging are thus constructed through landscape and praxis rather than blood or birth. Crucially, however, Pigeon Post deploys this link with the landscape to establish the identity of English characters, rather than as a means of demonstrating (as Spring and Streatfeild do) that refugee populations can become English or British. Pigeon Post, then, reflects the turn towards the 'identity-endowing properties of place' as a means of constructing Englishness that Ian Baucom identifies as a response to the problems posed by the relationship between Britain and its empire, understood as 'less a place where England exerts control than the place where England loses command of its own narrative of identity' (3).

The themes established in Pigeon Post proliferated in many of the winners over the next twenty years, which Lucy Pearson suggests promote 'a sense of nationhood which is predicated on rediscovering history, heritage, and the rural landscape' ('Home, Heritage, History' 209). However, heritage construction is far from neutral: if heritage becomes 'the embodiment of the spirit of the nation' then 'those who cannot see themselves reflected in its mirror cannot properly belong' (Hall 22). The heritage constructed in the Carnegie Medal's first two decades was almost exclusively English: the vast majority of winning titles were set 
Pearson, L, Sands-O-Connor, K and Subramanian, A, 'Prize Culture and Diversity in British Children's Literature', International Research in Children's Literature 12:1 (2019), 90-106.

wholly or partly in England and written by English authors. In fact, when formal criteria were first published in 1941 they limited eligibility to English authors (see Pearson, 'Home, Heritage, History' 212). This was changed in 1944 to 'a British subject domiciled in the United Kingdom' ('L.A. Council Notes' 96), enabling the committee to award the 1944 Medal to Eric Linklater's The Wind on the Moon. A Scottish nationalist born in Wales to an Orcadian father, Linklater certainly represented a more pluralistic view of the nation, but this was not to prove a lasting shift. Of seventy-two authors who had won by 2018 , sixty-one were English, compared to only six from the other three nations. These comprise three Scottish authors (Linklater, Theresa Breslin and Mollie Hunter); two Irish (Sarah Crossan and C. S. Lewis; English-born Siobhan Dowd had Irish parents and won for a novel set in Ireland) and only one Welsh (Ronald Welch). While other winners have acknowledged the hybrid quality of Britishness - notably Rosemary Sutcliff's The Lantern Bearers (1959) - the list as a whole emphatically does not hold a mirror up to the four nations of the United Kingdom.

The question of mirrors, and who is and is not reflected in them, has been a recurrent theme in the field of children's literature, especially in relation to race. In recent years the We Need Diverse Books movement has revisited Rudine Sims Bishop's metaphor of 'windows, mirrors and sliding glass doors' to make the case for the importance of books that reflect the diversity of lived experience (Bishop, Mabbot). If the shifting criteria for the Carnegie Medal in its first two decades implicitly acknowledge that the borders of Britain and Britishness are far from stable, its construction of a primarily English heritage effectively seeks to repudiate the racial and cultural implications of this instability. The early Carnegie Medal winners rarely depicted other cultures, but those that did constructed a sense of otherness against which white, English culture was positioned as the norm. Richard Armstrong's Sea Change (1948), for example, follows a young merchant seaman at the start of his career and features 
Pearson, L, Sands-O-Connor, K and Subramanian, A, 'Prize Culture and Diversity in British Children's Literature', International Research in Children's Literature 12:1 (2019), 90-106.

key scenes set in Trinidad, then part of the British Empire. The soldiers manning the fort in Port-of-Spain are not presented as fellow British citizens but as profoundly other: the fort's sentry (asleep on duty) is 'the strangest soldier Cam had ever seen' (92) and none of the Trinidadian soldiers appear to speak English. Other Carnegie winners that venture overseas (or even outside England) are historical novels, including two biblical retellings: Rosemary Harris's The Moon in the Cloud (1968) and Peter Dickinson's City of Gold (1979). An imperial legacy is present in the birthplaces of four 'English' winners - Jamaica (Eleanor Dooley), Canada (Philip Turner), Egypt (Penelope Lively) and the former Rhodesia (Peter Dickinson) - but not in the ethnicities of authors or the protagonists of their novels.

\section{Capital and Criteria}

Shifting criteria around nationality in the early decades of the Carnegie Medal must be set against the context of its developing profile. Kidd notes that the prizing of children's literature implies an attempt 'to assert its value beyond the merely or crudely utilitarian' (167). This motivation is certainly evident in the establishment of the Carnegie Medal, the main reason for which was 'to promote the idea of quality in children's books, to mark out "really fine work in this field"” (Barker, Realms 17). A new prize, however, must simultaneously confer cultural capital on its chosen field and demonstrate that it has capital to confer. One way of establishing this authority is to select an 'uncontestable' winner: this may have contributed to the choice of the already well-established Arthur Ransome over thenbeginners Streatfeild and Spring. The announcement of the award devotes as much space to Ransome's body of work as a whole as to Pigeon Post, which is described as 'just one more of this excellent series' ('Library Association Carnegie Medal and Mr Arthur Ransome', 219). The announcement also specified that Pigeon Post had been chosen over its competitors because it was not a book for boys or girls, but one which would have a 
Pearson, L, Sands-O-Connor, K and Subramanian, A, 'Prize Culture and Diversity in British Children's Literature', International Research in Children's Literature 12:1 (2019), 90-106.

'universal' appeal (218). 'Universal' may apply to gender, but not to class or age of reader; Swallows and Amazons (1930) opens with a quotation from Keats's 'On First Looking into Chapman's Homer', which signals the series' connection to the tradition of adventure writing and to literary culture as a whole. The choice of Ransome as inaugural winner thus served to establish the idea of literary quality that would be honoured by the Medal, one which is assumed to be 'universal'.

English points to the selection of judges as another important factor in the delicate business of claiming and conferring prestige (122-4); it is perhaps because of the marginal status of children's literature that the initial selection committee was composed of, per Barker, 'four dignitaries of the Library Association' and nominations were to be invited from 'the chief librarians of "many important libraries"' (Realms 4). No specialist children's librarians were directly involved in the process, reinforcing a notion of 'universal' literary quality that could be established without consideration of audience. The Medal as initially described was designed to honour 'a book for a child somewhere between the ages of nine and twelve' ('Library Association Carnegie Medal and Mr Arthur Ransome', 218). When the 1937 Medal was awarded to Eve Garnett's The Family from One End Street - a notable early example of a book focusing on working-class life - the announcement indicated that the judges had considered its appeal to child readers, commenting, 'We begin to think we have met these children before. We have. They are in our own children's libraries' (“"The Family from One End Street"' 251). In practice, however, few of the judges worked directly with children: despite the efforts of children's librarians like Eileen Colwell to secure representation on the committee for people 'in active touch with children's books' (Colwell, 14), only a handful of children's librarians served on the committee up until the 1960s (Barker, Realms 3-12). Furthermore, the formal written criteria for the Medal have never mentioned children, despite multiple revisions across its history. Crucially for consideration 
Pearson, L, Sands-O-Connor, K and Subramanian, A, 'Prize Culture and Diversity in British Children's Literature', International Research in Children's Literature 12:1 (2019), 90-106.

of the Medal as a means of constructing a 'national' literature, the criteria push against an idea of books as 'mirrors' for a particular audience and towards a 'universalising' understanding of aesthetic worth.

\section{A Logic of Proliferation: The Guardian Award}

By the 1960s, the Carnegie Medal's construction of quality was becoming the focus of criticism from both within and without the Library Association. From 1950 onwards, the Oxford University Press had been disproportionately represented among the winners; by 1964 its dominance had come to be regarded as almost a given (Barker, Realms 20). Aidan Chambers was one of many critics of this state of stagnation, stigmatising the Carnegie winners as 'intellectual, sophisticated, over-written, unremarkable for anything in the slightest "questionable" in thought, word or deed" and suggesting that this contributed to the phenomenon of the 'reluctant reader' (67). Chambers, like many others involved with children's books in the 1960s, including teachers and librarians, came from a working-class background (see Pearson, Making). The children's book world as a whole was thus shifting to reflect a different picture of the nation, and this produced an increased interest in the idea of children's books as mirrors. Two new awards embraced this interest: The Guardian newspaper's prize for children's fiction, first awarded in 1967, and the Other Award, first awarded in 1975.

The Guardian prize for children's fiction was instituted by John Rowe Townsend who, while working as features editor and children's book reviewer for The Manchester Guardian in the early 1960s, had accompanied an officer for the National Society of Prevention of Cruelty to Children (NSPCC) for the purpose of research. Townsend was struck by the contrast between the lives of children he saw during those few days and the 'happy children with ponies and boats and holiday adventures who featured in the children's 
Pearson, L, Sands-O-Connor, K and Subramanian, A, 'Prize Culture and Diversity in British Children's Literature', International Research in Children's Literature 12:1 (2019), 90-106.

books he reviewed' ('More About John Rowe Townsend'). The experience prompted Townsend to begin writing his own children's fiction focused on the lives of the urban poor and in 1965 - following widespread criticism of the Carnegie's selection of another 'holiday adventure', Philip Turner's The Grange at High Force - to establish the Guardian prize. The prize, announced in 1966, would give 'an annual award of one hundred guineas for an outstanding contribution to children's literature [...] chosen by a panel of Guardian reviewers under the chairmanship of the children's book editor' (Eyre 183-4). Townsend intended the award to act as a counterweight to the Carnegie: in a tactful address to the Library Association in 1978 he suggested 'that an award which was made and administered by a particular body of people might tend to go to the same kind of book' and that 'another view of the field would be interesting, and stimulating in a rather different kind of way' (Townsend 183). The Guardian prize certainly did serve, as Townsend suggested, to 'spread around' the glory (183): in its first two decades, the two awards had only four authors in common across their winners, and only two books won both awards.

Nevertheless, by 1978 Townsend reflected that 'There has been rather more overlap between the "Guardian" and the "Carnegie" than I expected' (184). This may have resulted from the fairly static composition of the Guardian judges' panel: writing in 1985, Robert Leeson pointed out that children's book reviewers were 'a fairly small circle' and the fact they included 'not a few writers [...] reinforced the sense of an inner circle' (123-4). Furthermore, a number of those author-judges also fitted into the Carnegie model of quality: the first committee included Philippa Pearce, who had won the Carnegie for Tom 's Midnight Garden (1958), and of the five judges on the last committee chaired by Townsend, Nina Bawden had been Carnegie shortlisted (for Carrie's War, 1973) and Peter Dickinson would go on to win the Medal in the following two years, for Tulku (1979) and City of Gold (1980). The terms on which the Guardian Award was judged also closely resembled those of the 
Pearson, L, Sands-O-Connor, K and Subramanian, A, 'Prize Culture and Diversity in British Children's Literature', International Research in Children's Literature 12:1 (2019), 90-106.

Carnegie: the award was to go to an 'outstanding' book and the judges were to be 'concerned essentially with literary quality', not with the question of how a book might be received by child readers ('Guardian prize-winner'). Beyond this, Townsend had strongly resisted the use of written criteria, arguing that 'a good critic can discern excellence' but that 'one cannot say in the abstract that certain qualities add up to excellence' (Townsend 184). As with the Carnegie, there was no impetus to consider whether 'excellence' might differ depending on the beholder.

Overlap between the Guardian Award and the Carnegie does not indicate that the newer award was without effect, however. On the contrary, it was one of several factors that helped to create change in prize culture. Widespread criticism of the Carnegie, and the existence of competition, helped advocates for change within the Library Association, including many specialist children's librarians. When Eileen Colwell had called for the involvement of more people 'in active touch with children's books' in 1944, there had been relatively few professionals in this position. By the 1960s, children's librarianship was at its height in terms of both numbers and expertise (many library schools offered specialist courses on children's books). This new generation of librarians were more likely to come from working-class backgrounds and, thanks to growing library provision, more likely to be working directly with children in deprived communities.

Many criticised the failure of the Carnegie Medal to honour books that would interest a wider range of children. Janet Hill, Children's Librarian for the London borough of Lambeth, actively promoted the idea that children's books should function as a 'mirror' for their readers; her efforts to find books reflecting the Lambeth community led to her produce an annotated bibliography of children's books about immigrant communities for the Institute of Race Relations (Sands O'Connor 34). Hill judged the 1966 Carnegie, when several of the publications committee had not attended the final judging meeting and the Medal had 
Pearson, L, Sands-O-Connor, K and Subramanian, A, 'Prize Culture and Diversity in British Children's Literature', International Research in Children's Literature 12:1 (2019), 90-106.

ultimately been withheld (the only instance of failure to award outside the war years). This intensified her belief that awards like the Guardian might provide a model for structural change in the Carnegie. An argument that raged in the letters page of the Times Literary Supplement in 1968 directly referenced the Guardian Award: Peggy Heeks, Chairman of the Youth Libraries Group, complained that the authority and credibility of this award was not subject to the scrutiny directed at the Carnegie Medal (Heeks). Hill countered that this was because - unlike the Carnegie - 'Their choices have been generally acceptable, their published justification lucid and intelligent' (Hill). Ironically, the 1968 Carnegie Medal had gone to the Guardian Award-winning The Owl Service (1967) by Alan Garner, arguably the most narratively and ideologically radical winner up until that point. The choice reflected wider changes taking place behind the scenes; later in 1968 a wholesale revision of the Medal was announced. The committee would now be composed of the chairman, vice-chairman and honorary secretary of the Youth Libraries Group along with seven others, including at least some whose jobs involved day-to-day contact with children (Barker, Critical History 28). Like the Guardian committee, then, the new Carnegie committee represented a different perspective from that which had prevailed in the 1940s and 1950s. As a result, the 1970s saw the two awards reflect a wider range of British society, honouring books by working-class authors and about working-class experience such as Robert Westall's The Machine Gunners (1975).

\section{Questions of Diversity: The Other Award}

A far greater challenge to the construction of a national children's literature came in 1975, in the form of the Other Award. Unlike the Carnegie and Guardian awards, the Other Award was explicitly concerned with the question of 'mirror' literature. Rosemary Stones and Andrew Mann, the editors of Children's Book Bulletin, set up the award because, according 
Pearson, L, Sands-O-Connor, K and Subramanian, A, 'Prize Culture and Diversity in British Children's Literature', International Research in Children's Literature 12:1 (2019), 90-106.

to Mann, 'most current children's books reflect a narrow and privileged section of the population' (Mann 142). Accordingly, award criteria focused on content as well as literary style, celebrating 'those writers and illustrators who are making available to children a wider and more accurate representation of human experience and situation' (Triggs 11). Notably, the criteria included whether the book was one 'which children will enjoy', placing this before 'literary merit', and stipulated that it should contain 'realistic depictions of all people, whatever their culture, background or occupation' (Stones, 'Other Winners' 866). Because of the broad aims of the award, and because they lacked funds to give any cash prize, the judges were not restricted to a single winner; in the first year they chose three, all of which contained working-class characters. For Mann and Stones, however, a wider representation of experience was not limited to the working class. The Other Award had an explicit feminist agenda and, notably for representation of the nation, its mission to honour 'realistic depictions of all people' extended to Britain's minority populations. Notwithstanding the involvement of Janet Hill, the reforms of the Carnegie Medal had failed to produce any meaningful representation of Black, Asian and minority ethnic (BAME) Britons: Lucy Boston's A Stranger at Green Knowe (1961) remained the only Carnegie winner to feature a non-white protagonist (a Chinese refugee). By contrast, inaugural winners of the Other Award included two books featuring Black British characters: Jean MacGibbon's Hal and Dorothy Edwards's Joe and Timothy Together. Two years later, it would become the first of the three awards to go to a non-white author, Indian-born Farrukh Dhondy, for his collection of short stories East End at Your Feet (1976).

The Other Award criteria were not simply focused on 'mirror' literature; they advocated for books that did not 'condone or take for granted the implicit or explicit values of competitive individualism, the accumulation of wealth, hierarchical social organisation, the inevitability of superior/inferior social categories' (Stones, 'Other Winners' 866). Over 
Pearson, L, Sands-O-Connor, K and Subramanian, A, 'Prize Culture and Diversity in British Children's Literature', International Research in Children's Literature 12:1 (2019), 90-106.

the next decade the award went to increasingly radical texts, perhaps in response to increasingly tense race relations in Britain and global struggles linked to earlier European imperialism. In 1980, for example, they commended Young World Books, an arm of the communist publisher Liberation, for producing - among other works - Pepetela's Nguga's Adventures, 'the story of a 13 year old boy growing up in the midst of the Angolan war of liberation' (Stones and Mann 16). In 1982, the year following the Brixton riots, the Other Award was given to Keith Ajegbo's Black Lives White Worlds, a collection of stories 'that all tackle the relationship of Black people to white society, while also providing a record of changing Black consciousness' (16). The Other Award thus honoured books that not only reflected British society more fully, but also encouraged readers to question that society.

The Other Award was short-lived. Rosemary Stones, writing in 1988, explained that the award's demise was partly due to financial constraints, but also because:

We no longer think an award is an appropriate way to promote 'other' concerns. In 1975 the Other Award was established as an irritant and counter to the Carnegie, the Kate Greenaway, and the Guardian awards. In these Smarties days, it's hard enough to see the books for the plethora of awards getting in the way. ('13 Other Years' 53)

Stones and Mann could point to some evidence that the Other Award had served as an 'irritant' to its counterparts in relation to gender and class; in 1977 its values on these issues had intersected so far with the Carnegie as to produce the same winner, Gene Kemp's The Turbulent Term of Tyke Tiler. Stones's sense that it was not effective in promoting 'other' concerns, however, reflects the fact that many of these concerns had remained 'other'. Lance Salway, writing in 1976, had suggested that the establishment of the Other Award meant that complaints about the failure of the Carnegie Medal to 'reflect the social realities of our time' had been 'satisfied elsewhere' (888). The desire to reflect the realities of Britain's increasingly multi-ethnic society was certainly not satisfied within the Carnegie. While a few 
Pearson, L, Sands-O-Connor, K and Subramanian, A, 'Prize Culture and Diversity in British Children's Literature', International Research in Children's Literature 12:1 (2019), 90-106.

winning novels did include non-white characters, they tended to be historical works, such as Peter Dickinson's 1979 winner Tulku, fantasy or folktale, like Susan Price's The Ghost Drum, which won in 1987. While these later Carnegie winners did venture outside the bounds of white, English society, they continued to position alternate identities as decidedly other.

Changes in the Guardian Award in the 1980s suggest that the Other Award was a slightly more successful 'irritant' to this award. John Rowe Townsend stepped down as head of the Guardian committee in 1978; his successor, Stephanie Nettell, brought a different perspective on the award's mission, focusing less on a purely aesthetic judgement of literary quality. Writing in 1990, she said: 'I could never be happy with a winner that contradicted those [...] social, political and moral principles [...] The Guardian and I myself believe are important' (Nettell 109). Under Nettell's tenure, the Guardian awarded the first mainstream children's book prize to an author of colour in 1983: Anita Desai for The Village by the Sea. Set in India, Desai's novel did not include British characters of colour; Desai's Booker Prize success the previous year also meant her work carried a good deal of cultural capital, helping to make a claim for literary quality. However, it marked the Guardian prize as moving beyond the boundaries of English books for British children: the award announcement noted that there had been a number of Commonwealth authors on the shortlist and imagined 'an international world of childhood, with no boundaries' (Guardian Children's Award, 1983 11). In 1988, following the demise of the Other Award, the Guardian again broke new ground: Ruth Thomas's The Runaways was the first Guardian prize-winner to have a Britishborn Black character as a protagonist.

The choice of Thomas's novel indicates some progress in who is seen as British, but race is less central to the book than it first appears. Thomas uses race as more a narrative than a political strategy: 
Pearson, L, Sands-O-Connor, K and Subramanian, A, 'Prize Culture and Diversity in British Children's Literature', International Research in Children's Literature 12:1 (2019), 90-106.

I made my central characters a boy and a girl, one black and one white, not just because I was aware from my own experience of how great was the need for stories with which black children could identify, but also to start them off as different from each other as they could possibly be. Then they could discover for themselves their common humanity. (Eccleshare 41)

Thomas is careful to include other minority characters in the novel who are different from Nathan, the main Black character: there is the 'goody goody' Sanjay (Thomas 5), contrasting with Nathan's sullen attitude, and Sharon, 'a muscular black girl, good at games and immensely popular' (7) and the complete opposite of Nathan in every way except race. Yet Nathan does not run away with Sharon - who quickly disappears from the text - but Julia, a white girl with learning disabilities who, like Nathan, is a class outcast. Racial difference is not based on culture (Nathan's reading tastes are decidedly middle class, as he takes them to Exmoor because he once read Lorna Doone) but on surface (skin-level) attributes, making it easier for the characters to find their 'common humanity'.

The idea of a 'universal world of childhood' linked by 'common humanity' may have led the Guardian Award to a more inclusive set of winners, but in many respects it preserves the assumptions present in Berwick Sayers' 1937 suggestion that the Carnegie winners should have a 'universal' appeal ('Library Association Carnegie Medal' 1937). Despite the gradual move towards more diverse representations of the nation, national identity is still constructed through a set of 'common' cultural values that are predominately white, English and (to a lesser extent) middle class. 'Other' identities must be positioned either as closely aligned with these values or - as in the early Carnegie and Newbery winners - as 'exotic, primitive and other' (Kidd 177). Thus Scotland, Wales and (Northern) Ireland are represented in both the Guardian and the Carnegie awards predominately through historical novels, and often filtered through the eyes of English authors, as in Alan Garner's The Owl Service and Joan Aiken's The Whispering Mountain (the 1969 Guardian Award winner). The few 
Pearson, L, Sands-O-Connor, K and Subramanian, A, 'Prize Culture and Diversity in British Children's Literature', International Research in Children's Literature 12:1 (2019), 90-106.

Carnegie winners featuring non-white protagonists continue to represent them as outsiders to Britain - as in Beverly Naidoo's tale of Nigerian refugees, The Other Side of Truth (2000) or they are set outside the UK entirely (Tanya Landman's Buffalo Soldier, the 2015 winner, features an African American protagonist). While powerful novels, they do little to suggest that non-white experience is integral to British national identity.

\section{Prestige and Otherness: The Twenty-First Century}

The way the Carnegie Medal constructed a national literature was closely connected to a desire to claim cultural capital for children's literature. Keith Barker shows that over the lifetime of the award criticisms of its failure to honour books that reflected the diversity of British society or that appealed to a wide range of child readers were frequently met with an emphasis on the Medal's mission to award literary quality (Realms 23-6). The transition to the twenty-first century marks another crucial shift in the position of children's books in Britain, with the establishment of the post of Children's Laureate in 1999. This two-year post, proposed by Ted Hughes (the Poet Laureate at the time) and Michael Morpurgo, is awarded to a major figure in the fields of children's literature and illustration. Nicholas Tucker links the establishment of the position to a desire to counter a general decline in the structures that had sustained children's literary culture. Although the Children's Laureate has no formal state position, the choice of title implies equivalence to the Poet Laureate, who is appointed by the monarch. Unlike the Poet Laureate, who has few specific duties, the Children's Laureate was designed as an active figure, taking part in a minimum of four major events over the two-year period, and 'highly visible at all times' (Tucker 49). The Children's Laureate thus serves as a public face for a national children's literature, advocating for the field and enshrining it within the national culture. 
Pearson, L, Sands-O-Connor, K and Subramanian, A, 'Prize Culture and Diversity in British Children's Literature', International Research in Children's Literature 12:1 (2019), 90-106.

An increase, however slight, in the visibility of BAME writers within the field of children's literature was contemporaneous with the appointment of black writer Malorie Blackman as Children's Laureate for the period 2013-15 and with a broader global conversation about racial representation in children's literature, exemplified by the American We Need Diverse Books campaign, initiated in 2014 by US authors Ellen Oh, Malinda Lo and Aisha Saeed (E. Thomas 113). In the UK, some more recent prizes have - like the Other Award - presented themselves as interventions into the larger field of British literary culture. The Jhalak Prize, founded in 2016 by authors Sunny Singh and Nikesh Shukla with the Media Diversified organisation, is a juried award celebrating work by British or Britishresident BAME writers. Kiran Millwood Hargrave's children's books appeared on the 2016 and 2017 shortlists, and BAME children's authors Catherine Johnson and Alex Wheatle have served on the panel of judges. The Little Rebels Children's Book Award, begun in 2012 and administered by the Alliance of Radical Booksellers as a children's counterpart to the Bread and Roses Award for Radical Publishing, does not specify an interest in racial diversity but describes as 'radical' any book that is informed by 'anti-discriminatory, environmental, socialist, anarchist, [or] feminist concerns', 'promotes social equality or challenges stereotypes and/or the status quo' or 'promotes social justice and a more peaceful and fairer world' ('Submitting a Book'). Previously shortlisted books by BAME authors included Millwood Hargrave's The Girl of Ink and Stars (2017), Yasmeen Ismail's I'm a Girl! (2016), Brahmachari's Tender Earth (2018) and Malala Yousafzai and Kerascöet's Malala's Magic Pencil (2018). The 2018 winner, Zanib Mian's The Muslims, is framed as an explicit response to anti-Muslim bigotry in the UK, through the conceit of a first-person narrator, Omar, who addresses an unspecified wider audience and attempts to demystify his Muslim family by means of labelled pictures, glossaries and exhortations not to be afraid. 
Pearson, L, Sands-O-Connor, K and Subramanian, A, 'Prize Culture and Diversity in British Children's Literature', International Research in Children's Literature 12:1 (2019), 90-106.

As the earlier example of the Other Award suggests, however, it is not clear that specialised awards can materially affect the larger landscape of national children's literature. Discussing the Pura Belpré Medal, presented by the American Library Association to Latino/a writers, Marilisa Jiménez García argues that 'book prizes based on race and ethnicity $[\ldots]$ have done little to rupture the racial politics of the children's literary world' (104). Although the Guardian Award has reflected the slight shift towards BAME visibility in the last decade, the period 2000-17 did not see a similar shift in the Carnegie Medal. In 2016, a more explicit emphasis on social justice was introduced in the Carnegie/Greenaway medals with the addition of the Amnesty CILIP Honour for books that 'best illuminate, uphold, or celebrate human rights' ('Amnesty CILIP Honour'). However, the winner of this award is chosen from books shortlisted for the CILIP Carnegie and Kate Greenaway Medals, and criteria relating to human rights were not simultaneously introduced into the nomination or shortlisting processes. Characters of colour occasionally featured in shortlisted works during this period, but their inclusion was largely limited to variations on what Christopher Myers describes as 'the townships of occasional historical books that concern themselves with the legacies of civil rights and slavery' ('Apartheid'). Tanya Landman's Buffalo Soldier (2015 winner), Robin Talley's Lies We Tell Ourselves (2016 Amnesty Honour winner) and Susan Cooper's Ghost Hawk (2014 shortlist) detail racial conflict at particular moments in American history, while Geraldine McCaughrean's The Middle of Nowhere (2015 shortlist) dramatises interracial clashes in nineteenth-century Australia; all these books are set outside the borders of Britain, and all are by white authors. Other books featuring non-white characters, such as Rachel Campbell-Johnson's The Child's Elephant (2014 shortlist) and Elizabeth Laird's The Fastest Boy in the World (2015 shortlist), take place in Uganda and Ethiopia respectively. The cumulative effect is a sense that histories of racism and non-white identities are extrinsic to British culture. 
Pearson, L, Sands-O-Connor, K and Subramanian, A, 'Prize Culture and Diversity in British Children's Literature', International Research in Children's Literature 12:1 (2019), 90-106.

The choice of Alex Wheatle's Crongton Knights for the 2017 Guardian prize highlighted the failure of the Carnegie Medal to include BAME voices in the national story represented by its prize-winners. The year had seen publication of books by highly regarded BAME authors, including Wheatle, Blackman, Millwood Hargrave and Patrice Lawrence. All these authors had received other prizes, and Wheatle's novel had been highly praised by Guardian judge David Almond, who wrote that it 'hums with the beat of real life and the language sings from the page' (Armitstead). Yet the 2017 Carnegie longlist contained not one BAME author. Speaking at the Diverse Voices? symposium at Seven Stories, the UK's National Centre for Children's Books, in November 2017, Wheatle said that following this omission, 'I felt [. . . ] that otherness, that feeling of being different wasn't quite adjudicated for' (Wheatle). Wheatle's comment astutely highlights the nature of identity-building within the Carnegie Medal: otherness is always presented in counterpoint to British identity, never as integral to it. The selection of Angie Thomas's The Hate U Give for the 2018 shortlist did little to challenge this trend: the first shortlisted book by an author of colour since R. J. Palacio's Wonder in 2013, this powerful novel is by an African American writer and about racial politics in the USA. Race and racism continue to be issues 'out there', not 'over here'. Furthermore, the fact that it was ultimately passed over for the main Carnegie Medal (despite strong support from children who 'shadowed' the award) but awarded the Amnesty CILIP Honour raises the possibility that the latter award might function as a way of displacing socially motivated books from the main orbit of the Carnegie Medal.

\section{Adjudicating Otherness}

Questions of national identity have been very evident in the shifting eligibility criteria of the Carnegie Medal, yet these criteria have been understood as simply bureaucratic, rather than fundamental to evaluation of the books themselves. By emphasising an elusive notion of 
Pearson, L, Sands-O-Connor, K and Subramanian, A, 'Prize Culture and Diversity in British Children's Literature', International Research in Children's Literature 12:1 (2019), 90-106.

literary quality, the Medal has rendered invisible the ways that questions of identity might affect this evaluation. Indeed, CILIP CEO Nick Poole responded to criticisms of the all-white 2017 longlist by emphasising that:

The books on the longlist are judged on merit and on an equal playing field. This year's longlist represents, in the opinion of the judges, the very best books of the year, with no consideration of gender or ethnicity of either the writer, illustrator or audience. (Onwuemezi) This response failed to consider whether the judges might bring their own cultural values to the task of distinguishing 'the very best books of the year'. In fact, the development of the Carnegie, Guardian and Other awards in the twentieth century points strongly to the fact that unless criteria explicitly consider socio-political dimensions such as gender or ethnicity, 'literary quality' will tend to privilege some voices over others. Alternative awards have helped to diversify the picture of the UK presented in British children's literature, but speakers at the Diverse Voices? symposium were unanimous in their sense that the Carnegie Medal continues to occupy a unique role in terms of prestige and impact on authors' careers: its elevation of particular voices thus serves to doubly marginalise those who are not included.

Despite Poole's initial defence, the widespread criticism directed at the 2017 longlist ultimately prompted CILIP to engage with this problem directly. With the strong support of then-chair of the judges, Jake Hope, they appointed the chair of ActionAid UK, Margaret Casely-Hayford, to head an independent review into 'how equality, diversity, inclusion and participation can best be championed and embedded' into the Carnegie and its sister award, the Kate Greenaway ('CILIP Carnegie’ 1). Casely-Hayford's report recommended that CILIP 'Explicitly champion diversity' (5) through its awards and suggested that one way of achieving this was 'the inclusion of criteria for innovation, shifting perceptions, or writing about different backgrounds and experience as indicators of quality and excellence' (10). A 
Pearson, L, Sands-O-Connor, K and Subramanian, A, 'Prize Culture and Diversity in British Children's Literature', International Research in Children's Literature 12:1 (2019), 90-106.

revision of the criteria is currently underway; some more immediate recommendations have already been implemented, including an expansion of the nominations process to include nominations from external bodies such as the charity Inclusive Minds (13). The effects of this are evident in the fact that of the twelve longlisted authors for 2019, six were people of colour and one BAME author - Candy Gourlay - was shortlisted. However, no British BAME characters are represented in the shortlisted books: the Carnegie has not yet fully succeeded in incorporating diversity into its contemporary vision of the UK.

Sadia Habib writes, 'There is a danger that in solely championing British culture, history, values and identity from a middle-class White Eurocentric perspective, [other] ethnic, class and cultural heritages are viewed as marginal and insignificant' (117). The history of the Carnegie and its competitor prizes reveals how apparently neutral ideas of 'literary merit' in the UK have often been underpinned by just such a mono-cultural approach. As a comparison of discourses around different prizes reveals, this has arisen in part from the tendency to place 'utilitarian' questions of social impact in opposition to more abstract or aesthetic constructions of literary merit. Examining prizes and the discourse around them thus reveals unspoken assumptions that underpin the construction of national literatures. Prizes also offer an opportunity to rethink these assumptions; however, this must take place within mainstream prizes like the Carnegie as well as through 'alternative' prizes if it is to effectively construct a new national literature.

\section{Works Cited}

'The Amnesty CILIP Honour for Carnegie and Kate Greenaway'. Amnesty International UK. 28 September 2018. 25 October 2018_https://www.amnesty.org.uk/amnesty-ciliphonour-carnegie-and-kate-greenaway>. 
Pearson, L, Sands-O-Connor, K and Subramanian, A, 'Prize Culture and Diversity in British Children's Literature', International Research in Children's Literature 12:1 (2019), 90-106.

Anderson, Benedict. Imagined Communities: On the Origin and Spread of Nationalism.

Revised edition. London: Verso, 2006.

Armitstead, Claire. 'Alex Wheatle wins 2016 Guardian children's fiction prize'. The

Guardian 17 November 2016. 3 October 2018

<https://www.theguardian.com/books/2016/nov/17/alex-wheatle-wins-2016-guardian-

$\underline{\text { childrens-fiction-prize> }}$

Armstrong, Richard. Sea Change [1948]. Leicester: Knight Books, 1969.

'Awards Process'. The CILIP Carnegie \& Kate Greenaway Children's Book Awards. 25

October 2018 <http://www.carnegiegreenaway.org.uk/awards-process.php>.

Barker, Keith. In the Realms of Gold: The Story of the Carnegie Medal. London: Julia

MacRae Books, 1986.

---. The Carnegie Medal: A Critical History and Examination of the Award Given Annually

by Librarians for an Outstanding Book Written in English for Children. MLib Thesis:

University of Wales, 1985.

Baucom, Ian. Out of Place: Englishness, Empire, and the Locations of Identity. Princeton:

Princeton University Press, 1999.

Bishop, Rudine Sims. 'Mirrors, Windows and Sliding Glass Doors' [1990]. 1 February 2019

<https://scenicregional.org/wp-content/uploads/2017/08/Mirrors-Windows-and-

Sliding-Glass-Doors.pdf>.

'The Carnegie Medal'. The Library Association Record (January 1937): 1.

Casanova, Pascale. The World Republic of Letters. Trans. Malcolm DeBevoise. Cambridge, MA: Harvard University Press, 2004.

Chambers, Aidan. The Reluctant Reader. London: Pergamon Press, 1969.

'CILIP Carnegie and Kate Greenaway Awards: Independent Diversity Review Final Report'.

CILIP: The Library and Information Association, 2018. 2 November 2018 
Pearson, L, Sands-O-Connor, K and Subramanian, A, 'Prize Culture and Diversity in British Children's Literature', International Research in Children's Literature 12:1 (2019), 90-106.

<https://cdn.ymaws.com/www.cilip.org.uk/resource/resmgr/cilip/information_profess ional_and_news/press_releases/2018_09_ckgfinalreport/cilip_ckg_diversity_review_f $\underline{. p d f>}$.

Colwell, Eileen. 'Correspondence: The L.A. Carnegie Medal'. The Library Association Record 46 (January 1944): 14-15.

Eccleshare, Julia. 'Ruth Thomas'. The Guardian 28 September 2011. 41.

Edwards, Owen Dudley. British Children's Fiction in the Second World War. Edinburgh: Edinburgh University Press, 2007.

English, James. The Economy of Prestige: Prizes, Awards, and the Circulation of Cultural Value. Cambridge, MA: Harvard University Press, 2005.

Eyre, Frank. British Children's Books in the Twentieth Century. New York: Dutton, 1973.

“"The Family from One End Street” and Miss Eve Garnett'. The Library Association Record (June 1938): 251.

'Guardian Children's Award'. The Guardian 17 March 1983. 11.

'Guardian Prize-Winner'. The Guardian 31 March 1967. 12.

Habib, Sadia. Learning and Teaching British Values: Policies and Perspectives on British Identities. Palgrave, 2018.

Hall, Stuart. 'Whose Heritage? Unsettling “The Heritage”, Re-imagining the Post-Nation'. The Politics of Heritage, the Legacies of Race. Eds Jo Littler and Roshi Naidoo. Abingdon: Routledge 2004. 21-31.

Heeks, Peggy. 'Carnegie Awards'. Times Literary Supplement 20 June 1968. 649.

Hill, Janet. 'Carnegie Awards'. Times Literary Supplement 27 June 1968. 679.

Jiménez García, Marilisa. 'The Pura Belpré Medal: The Latino/a Child in America, the “Need” for Diversity, and Name-Branding Latinidad'. Prizing Children's Literature: 
Pearson, L, Sands-O-Connor, K and Subramanian, A, 'Prize Culture and Diversity in British Children's Literature', International Research in Children's Literature 12:1 (2019), 90-106.

The Cultural Politics of Children's Book Awards. Eds Kenneth B. Kidd and Joseph T. Thomas, Jr. Abingdon: Routledge 2017. 104-17.

Kidd, Kenneth. 'Prizing Children's Literature: The Case of Newbery Gold'. Children's Literature 35 (2007): 166-90.

'L.A. Council Notes'. The Library Association Record (November 1944): 196.

Leeson, Robert. Reading and Righting. London: Collins, 1985.

'Library Association Carnegie Medal'. The Library Association Record (January 1941): 8.

'Library Association Carnegie Medal and Mr Arthur Ransome, The'. Library Association Record (May 1937): 218-19.

Mabbott, Cass. 'The We Need Diverse Books Campaign and Critical Race Theory:

Charlemae Rollins and the Call for Diverse Children's Books'. Library Trends 65.4 (Spring 2017): 508-22.

Macleod, Mark. 'The Children's Book Council of Australia and the Judging of Literary Excellence'. New Review of Children's Literature and Librarianship 17.1 (2011): 2035.

Mann, Andrew. 'The Other Award'. Signal 18 (1975): 142-5.

'Margaret Casely-Hayford to lead diversity review of CILIP Carnegie and Kate Greenaway Medals'. CILIP: The Library and Information Association, 26 June 2017. 25 October $2018<$ https://archive.cilip.org.uk/news/margaret-casely-hayford-lead-diversity-

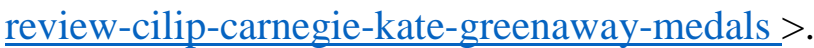

'More about John Rowe Townsend'. Green Bay Publications. 25 October 2018 〈http://www.greenbay.co.uk/jrt.html $>$.

Myers, Christopher. 'The Apartheid of Children's Literature'. The New York Times 15 March 2014, SR1. 2 November 2018 
Pearson, L, Sands-O-Connor, K and Subramanian, A, 'Prize Culture and Diversity in British Children's Literature', International Research in Children's Literature 12:1 (2019), 90-106.

<https://www.nytimes.com/2014/03/16/opinion/sunday/the-apartheid-of-childrens-

literature.html $>$.

Nettell, Stephanie. 'Children's Books: Always Back of the Queue?' Reading and Response.

Eds Mike Hayhoe and Stephen Parke. Buckingham: Open University Press 1990. $107-14$.

Onwuemezi, Natasha. 'CILIP Fends off Criticism over Lack of BAME Authors on Carnegie Longlist'. The Bookseller 16 February 2017. 25 October 2018 <https://www.thebookseller.com/news/cilip-defends-carnegiegreenaway-longlists$\underline{\text { after-criticism-over-lack-diversity-490446 > }}$.

Pearson, Lucy. The Making of Modern Children's Literature in Britain: Publishing and Criticism in the 1960s and 1970s. Farnham: Ashgate, 2013.

---. 'Home, Heritage, History: Renegotiating Identity in Postwar Children's Fiction'. Postwar: British Literature in Transition 1940-60. Ed. Gill Plain. Cambridge: Cambridge University Press, 2019. 209-24.

---. 'Prize Fighting: The Carnegie Medal and Children's Librarians'. Youth Library Review 47 (2017): 10.

Ransome, Arthur. Pigeon Post [1936]. London: Random House, 2001.

Salway, Lance. 'Kids’ Oscars’. Times Literary Supplement 16 July 1976. 888.

Sands-O'Connor, Karen. Children's Publishing and Black Britain, 1965-2015. Basingstoke: Palgrave Macmillan, 2017.

Sperling, S. V. 'A Brief History of Youth Libraries Group and CILIP's Carnegie and Kate Greenaway Awards'. CILIP YLG, 2006. 1 February 2019 <https://archive.cilip.org.uk/sites/default/files/documents/Brief\%20History\%20Websi te.pdf $>$.

Spring, Howard. Sampson's Circus. London: Faber \& Faber, 1936. 
Pearson, L, Sands-O-Connor, K and Subramanian, A, 'Prize Culture and Diversity in British Children's Literature', International Research in Children's Literature 12:1 (2019), 90-106.

Stones, Rosemary. '13 Other Years'. Books for Keeps 53, November 1988. 5 November 2018 <http://booksforkeeps.co.uk/issue/53/childrens-books/articles/other-articles/awards>.

---. 'The Other Winners'. Times Literary Supplement 15 July 1977. 866.

Stones, Rosemary and Andrew Mann. 'Other Award Exhibition Catalog 1985'. Rosemary Stones Collection. Seven Stories: the National Centre for Children's Books. Uncatalogued.

Streatfeild, Noel. Ballet Shoes [1936]. London: Puffin, 2015.

‘Submitting a Book’. Little Rebels. 6 March 2019 <https://littlerebels.org/submitting-a$\underline{\text { book/>. }}$.

Thomas, Ebony Elizabeth. ‘Stories Still Matter: Rethinking the Role of Diverse Children's Literature Today'. Language Arts 94.2 (November 2016): 112-19.

Thomas, Ruth. The Runaways. London: Red Fox, 1990.

Townsend, John Rowe. 'The "Guardian” Award'. LA National Conference (1978). 183-184. Triggs, Pat. 'The Other Award 1981'. Books for Keeps 11 (November 1981). 25 October 2018 <http://www.booksforkeeps.co.uk/issues/11/29676>.

Tucker, Nicholas. 'The United Kingdom Children's Laureate: The Story So Far'. Children's Literature in Education 45 (2014): 47-59.

Wheatle, Alex. 'Alex Wheatle on the CILIP Carnegie Medal and otherness'. Diverse Voices? Newcastle University and Seven Stories: the National Centre for Children's Books, April 2018. 25 October $2018<$ https://www.youtube.com/watch?v=mIjLUgjcrvU >.

<The Authors>

Lucy Pearson is Lecturer in Children's Literature at Newcastle University, UK. She is author of The Making of Modern Children's Literature in Britain (2013) and editor of 
Pearson, L, Sands-O-Connor, K and Subramanian, A, 'Prize Culture and Diversity in British Children's Literature', International Research in Children's Literature 12:1 (2019), 90-106.

Jacqueline Wilson: A New Casebook (2015). She is currently working on a history of the Carnegie Medal.

Karen Sands-O'Connor is Professor of English at SUNY Buffalo State College in the US. She researches issues of racial diversity in children's literature. Her most recent book is Children's Publishing and Black Britain 1965-2015 (Palgrave-Macmillan 2017).

Aishwarya Subramanian is a postdoctoral researcher, working on children's literature in postimperial Britain. Her current research focuses on political activism in late-twentieth and twenty-first century children's books 